\title{
Diagnosis and management of microscopic colitis: current perspectives
}

\author{
This article was published in the following Dove Press journal: \\ Clinical and Experimental Gastroenterology \\ 2I August 2014 \\ Number of times this article has been viewed
}

\author{
Johan Bohr ${ }^{1,3}$ \\ Anna Wickbom ${ }^{1,3}$ \\ Agnes Hegedus ${ }^{2}$ \\ Nils Nyhlin ${ }^{1,3}$ \\ Elisabeth Hultgren \\ Hörnquist ${ }^{3}$ \\ Curt Tysk ${ }^{1,3}$ \\ 'Division of Gastroenterology, \\ Department of Medicine, \\ 2Department of Laboratory \\ Medicine/Pathology, Örebro \\ University Hospital, Örebro, \\ ${ }^{3}$ School of Health and Medical \\ Sciences, Örebro University, \\ Örebro, Sweden
}

Correspondence: Curt Tysk

Division of Gastroenterology,

Department of Medicine,

Örebro University Hospital,

Örebro 70185, Sweden

Tel +4619602 1000

Email curt.tysk@orebroll.se

\begin{abstract}
Collagenous colitis and lymphocytic colitis, together constituting microscopic colitis, are common causes of chronic diarrhea. They are characterized clinically by chronic nonbloody diarrhea and a macroscopically normal colonic mucosa where characteristic histopathological findings are seen. Previously considered rare, they now have emerged as common disorders that need to be considered in the investigation of the patient with chronic diarrhea. The annual incidence of each disorder is five to ten per 100,000 inhabitants, with a peak incidence in 60 - to 70 -year-old individuals and a predominance of female patients in collagenous colitis. The etiology and pathophysiology are not well understood, and the current view suggests an uncontrolled mucosal immune reaction to various luminal agents in predisposed individuals. Clinical symptoms comprise chronic diarrhea, abdominal pain, fatigue, weight loss, and fecal incontinence that may impair the patient's health-related quality of life. An association is reported with other autoimmune disorders, such as celiac disease, thyroid disorders, diabetes mellitus, and arthritis. The best-documented treatment, both short-term and long-term, is budesonide, which induces clinical remission in up to $80 \%$ of patients after 8 weeks' treatment. However, after successful budesonide therapy is ended, recurrence of clinical symptoms is common, and the best possible long-term management deserves further study. The long-term prognosis is good, and the risk of complications, including colonic cancer, is low. We present an update of the epidemiology, pathogenesis, diagnosis, and management of microscopic colitis.
\end{abstract}

Keywords: microscopic colitis, collagenous colitis, lymphocytic colitis, chronic diarrhea, budesonide

\section{Introduction}

Microscopic colitis (MC), a mutual term for a group of inflammatory disorders of the colon described and evolving during the past few decades, has emerged as a common cause of chronic nonbloody diarrhea. ${ }^{1-3}$ As the name indicates, the condition can be diagnosed only by microscopic assessment of colonic mucosal biopsies. MC was earlier considered as rare, but is now diagnosed in up to $20 \%$ of patients undergoing colonoscopy for chronic diarrhea. The two most frequent forms of $\mathrm{MC}$ are collagenous colitis (CC) and lymphocytic colitis (LC). Characteristic symptoms are watery diarrhea, abdominal pain, weight loss, and fatigue that may impair the patient's health-related quality of life (HRQoL). Medical therapy has advanced, and currently budesonide is the only evidence-based effective therapy. However, despite the progress of knowledge, still many questions remain unsolved regarding the etiology, pathophysiology, and optimal management of MC. The condition is furthermore likely underestimated and overlooked in the clinical setting. This review gives an update on the epidemiology, pathogenesis, diagnosis, and management of CC and LC. 


\section{Epidemiology}

CC and LC, first described in $1976,4,5$ and in $1989,{ }^{6}$ respectively, have mainly been reported from European or North American centers, but the diseases are seen worldwide. ${ }^{7-10} \mathrm{An}$ incidence of five to ten per 100,000 inhabitants each for CC and LC has been found in population-based studies (Table 1). Two long-term epidemiologic series from Örebro, Sweden ${ }^{11-13}$ and Rochester, MN, USA ${ }^{14,15}$ show fairly similar patterns, with an increasing incidence during the 1980s and 1990s followed by more stable incidence. CC mostly affects middle-aged women, with a peak incidence around 60-70 years of age. However, the disease is seen in all age-groups, including children. ${ }^{16,17}$ In LC, peak incidence is seen in the same agegroup as CC, but female predominance is less prominent. ${ }^{18}$ Differences in background populations, environmental exposures, referral patterns, study design, or diagnostic criteria may account for the observed geographic variations in the occurrence of MC.

The prevalence of MC in Olmsted County, MN, USA in 2010 was 219 per 100,000 inhabitants: 90.4 per 100,000 for CC, and 128.6 per 100,000 for LC. ${ }^{15}$ In 2008, the prevalence of MC in Örebro was 123 per $100,000-$ CC 67.7 per 100,000 and LC 55.3 per 100,000 - underscoring the fact that these disorders are common and need to be considered in the investigation of patients with chronic diarrhea. ${ }^{13}$

\section{Clinical symptoms}

The clinical presentations of LC and CC are similar, and the diseases cannot be distinguished on clinical grounds.

Table I Annual incidence per 100,000 inhabitants reported in population-based epidemiological studies of collagenous colitis (CC), lymphocytic colitis (LC), and microscopic colitis (MC)

\begin{tabular}{|c|c|c|c|}
\hline Region and study period & CC & LC & MC \\
\hline Örebro, Sweden, 1984-1988"' & 0.8 & & \\
\hline Örebro, Sweden, 1989-1993"1 & 2.7 & & \\
\hline Örebro, Sweden, 1993-1998'2 & 4.9 & 4.4 & \\
\hline Örebro, Sweden, 1999-2008'3 & 5.3 & 5.0 & \\
\hline Olmsted County, USA, I985-1997/4 & 1.6 & 2.7 & \\
\hline Olmsted County, USA, |998-200I/4 & 7.1 & 12.6 & \\
\hline Olmsted County, USA 2002-2010 & 7.1 & 9.5 & 16.7 \\
\hline Calgary, Canada, 2002-2004'19 & 4.6 & 5.4 & \\
\hline Calgary, Canada, $2004^{20}$ & & & 16.9 \\
\hline Calgary, Canada, $2008^{20}$ & & & 26.2 \\
\hline Terrassa, Spain, 1993-199721 & 2.3 & 3.7 & \\
\hline Terrassa, Spain, 2004-200822 & 2.9 & 2.3 & \\
\hline Iceland, 1995-199923 & 5.2 & 4.0 & \\
\hline Denmark, 1999-201024 & 10.8 & 6.7 & \\
\hline Southern Sweden, $200 \mathrm{I}-2010^{25}$ & 5.4 & & \\
\hline Central Spain, 2008-201026 & $<1$ & 16 & 18 \\
\hline Uppsala, Sweden, 2005-2009 ${ }^{27}$ & 7.0 & 4.8 & \\
\hline
\end{tabular}

Both disorders cause chronic or recurrent watery diarrhea, often associated with urgency, nocturnal diarrhea, abdominal pain, and weight loss. ${ }^{3,28}$ The diarrhea can be severe, causing fecal incontinence especially in the elderly. The onset of disease can be sudden, mimicking an enteric infection..$^{18,29}$ Severe complications are infrequent, although a few cases of colonic perforations in $\mathrm{CC}$ have been reported, either spontaneous or after a colonoscopy. ${ }^{30,31}$ No increased risk of colorectal cancer has been reported in MC. The clinical symptoms may be misinterpreted as irritable bowel syndrome (IBS) and studies show that there is symptomatic overlap between MC and IBS. . $^{32,33}$

Abdominal pain is a common symptom, especially in patients with active disease. ${ }^{24,34}$ The pain is reported as cramping or dull, and is in most patients mild to moderate and seldom severe. Patients in clinical remission, ie, without diarrhea, still have a twofold-increased occurrence of abdominal pain compared to matched controls. ${ }^{34}$ The cause is unknown, but may represent IBS-like symptoms secondary to past or residual mucosal inflammation, as seen in quiescent ulcerative colitis or Crohn's disease. ${ }^{35}$

Fatigue is a frequent symptom both in $\mathrm{CC}$ and $\mathrm{LC}$, and reported by $50 \%-60 \%$ of patients. The cause is not well studied, but likely secondary to inflammation, disturbed sleeping caused by nocturnal diarrhea or associated diseases. Concomitant bile-acid malabsorption has been reported in $9 \%-60 \%$ of patients with $\mathrm{LC}$ and in $27 \%-44 \%$ of patients with CC. ${ }^{36-38}$ These findings are the basis for recommendations on treatment with bile acid-binding therapy in MC.

\section{Diagnosis}

The diagnosis of $\mathrm{MC}$ relies only on findings of characteristic histopathologic features in colonic mucosal biopsies.

\section{Laboratory analyses}

Routine laboratory tests are nondiagnostic, and only nonspecific abnormalities may be found, such as moderately increased levels of C-reactive protein, erythrocyte-sedimentation rate, or mild anemia. ${ }^{28}$ No pathological microorganisms are generally found in stool analyses. The diagnostic accuracy of fecal calprotectin and lactoferrin is low in MC in contrast to ulcerative colitis and Crohn's disease. ${ }^{39}$ Therefore, there has been a search for alternative biomarkers reflecting mucosal inflammation. In addition to the characteristic infiltration of lymphocytes, infiltrates of eosinophil granulocytes are seen in CC. ${ }^{40}$ They are regarded as proinflammatory cells with the ability to release cytotoxic proteins, such as eosinophil protein $\mathrm{X}$ and fecal eosinophil cationic protein. In a pilot study 
of 12 patients with active $\mathrm{CC}$, eosinophil protein $\mathrm{X}$ and fecal eosinophil cationic protein were positive in $67 \%$ and $92 \%$, respectively, and both markers decreased after budesonide treatment. ${ }^{41}$ The same research group reported increased levels of fecal neuropeptides, suggesting involvement of the enteric nervous system in the pathogenesis of CC. ${ }^{42}$ Levels of chromogranin A, chromogranin B, and secretoneurin were increased in 12 patients with CC compared both to controls and patients with ulcerative colitis or Crohn's disease. During budesonide therapy, levels of secretoneurin rapidly declined. ${ }^{42}$ These early data require further study and confirmation in bigger patient cohorts before they may be applied as potential biomarkers in MC.

\section{Imaging}

Imaging with radiology or endoscopy is usually normal, although minor mucosal changes can occasionally be seen, such as erythema, edema, and an abnormal vascular pattern. ${ }^{28}$ Colonic mucosal tears ("cat-scratch colon") are occasionally seen during colonoscopy, and might indicate an increased risk of colonic perforation during the procedure. ${ }^{43-45}$ Confocal laser endomicroscopy, which enables "real-time" microscopic imaging of the mucosa during endoscopy, may possibly allow in vivo diagnosis of $\mathrm{MC}$ in the future. ${ }^{46-48}$ However, clinical experience is currently limited, and the method is still a research tool.

\section{Histopathology}

The histopathologic criteria of MC have been reviewed recently. ${ }^{3,49}$ The characteristic histopathologic features of $\mathrm{CC}$ are a subepithelial collagen band $\geq 10 \mu \mathrm{m}$ in thickness in comparison with a normal basal membrane of $<3 \mu \mathrm{m}$. The collagen band often has an irregular, jagged aspect of the lower edge, and may contain entrapped capillaries, red blood cells, and inflammatory cells. Furthermore, the surface epithelium may show vacuolization, flattening, mucin depletion, and focal detachment from the basement membrane. An increased number of intraepithelial lymphocytes (IELs) may be seen, but this is not a prerequisite as in LC. In the lamina propria, slightly to moderately increased numbers of lymphocytes, plasma cells, and mast cells together with neutrophils and eosinophils are seen (Figure 1). Cryptitis does not exclude the diagnosis. In routine diagnosis, hematoxylin and eosin staining is sufficient, but in borderline cases, staining of the collagen band might be enhanced with tenascin immunostaining or Masson's trichrome.

The diagnosis of LC relies on an increased number of IELs. The exact cutoff level has not been determined, but $\geq 20$
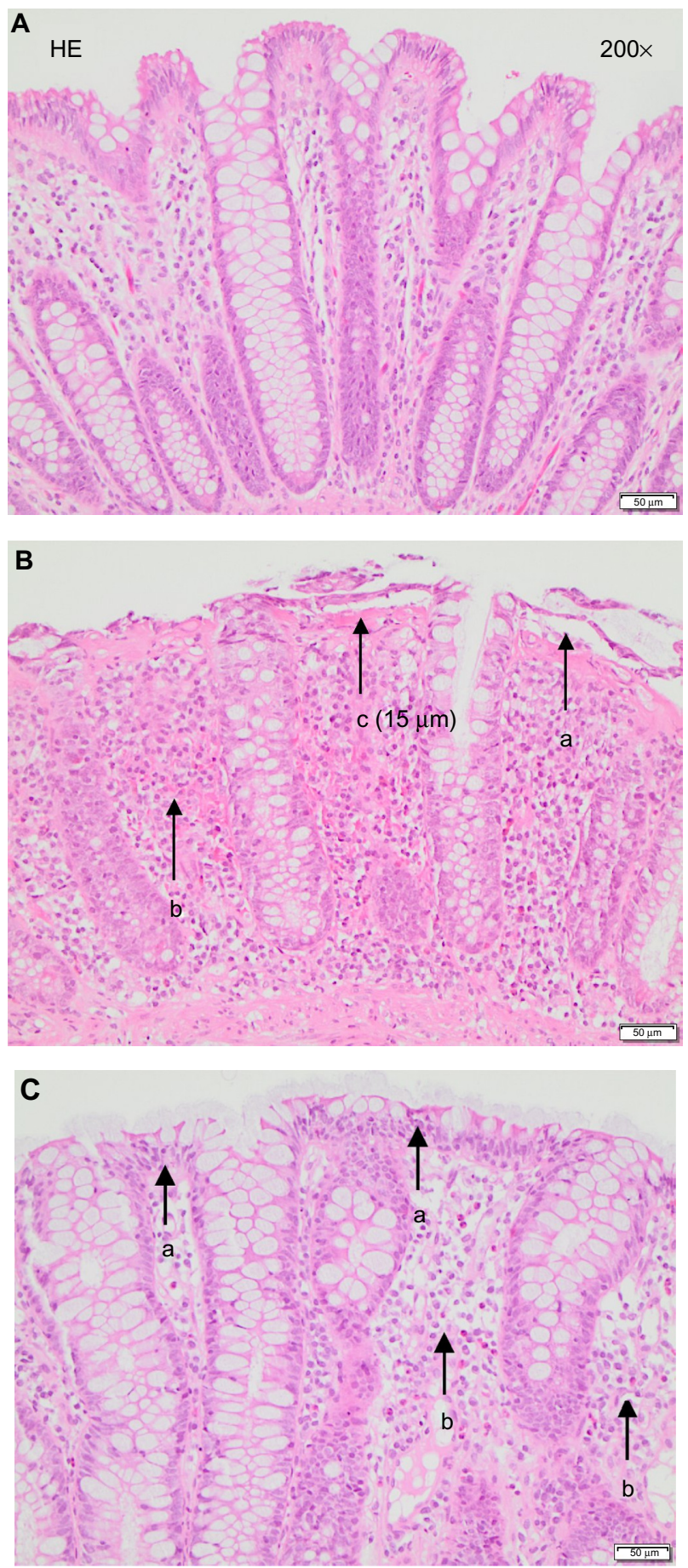

Figure I (A) Normal colonic mucosa. (B) Characteristic findings of collagenous colitis: detached and damaged epithelial cells (a), lamina propria inflammation (b), and thickened collagen layer (c). (C) Characteristic findings of lymphocytic colitis: epithelial cell damage with intraepithelial lymphocytosis (a) and inflammation in the lamina propria (b). Hematoxylin and eosin (HE) staining.

IELs per 100 epithelial cells is generally considered diagnostic for LC. ${ }^{49}$ In the normal colon, the number of IELs is reported to be fewer than five per 100 epithelial cells ${ }^{50}$ or four to ten per 100 epithelial cells. ${ }^{49}$ The epithelium may be damaged, showing the same changes as in CC. Lamina propria 
inflammation is seen as in $\mathrm{CC}$, with a mixed-cell infiltrate dominated by lymphocytes (Figure 1). Hematoxylin and eosin staining is usually sufficient in the diagnostic setting of LC, but CD3-lymphocyte immunostaining may be valuable in uncertain cases.

The topographic distribution of histopathological changes in $\mathrm{CC}$ is controversial. Characteristic findings may be unevenly distributed throughout the colon. It is generally accepted that the most prominent microscopic findings of $\mathrm{CC}$ are seen in the right and transverse colon, whereas rectal and sigmoid biopsies can be normal. The distribution of the histopathologic lesions has been reported recently in 187 CC patients, showing that lamina propria inflammation is found in the entire colon, whereas a thickened collagen layer is most prominent in the proximal colon, and can be absent in the descending and sigmoid colon. ${ }^{51}$ A sigmoidoscopy with biopsy is thus not sufficient for diagnosing $\mathrm{CC}$, and a pancolonoscopy with biopsies from the whole colon is required and will also rule out other colonic pathology. ${ }^{3}$

Other variants of MC have been reported, including incomplete $\mathrm{MC},{ }^{24} \mathrm{MC}$ not otherwise specified, ${ }^{52}$ and paucicellular LC. ${ }^{53,54}$ These patients have the same clinical features, but fall short of fulfilling the histologic criteria of CC or LC. They have an abnormal collagen layer - less than $10 \mu \mathrm{m}$ - or an increased number of IELs: fewer than 20 per 100 epithelial cells. Uncommon variants are MC with giant cells, ${ }^{55,56}$ pseudomembranous $\mathrm{CC},{ }^{57}$ cryptal LC (increased IELs limited to cryptal epithelium), ${ }^{58}$ and MC with granulomatous inflammation. ${ }^{59}$ The clinical presentations of these conditions resemble classic MC, but histopathologic features are different. More studies are required to address the occurrence, clinical significance, and management of these subtypes of MC. ${ }^{60}$

\section{Etiology and pathogenesis}

The cause of $\mathrm{MC}$ is not known, but is probably multifactorial. Currently, CC and LC are considered to represent specific mucosal responses to different thus-far-unidentified luminal agents in predisposed individuals, resulting in an uncontrolled mucosal immune response. ${ }^{28}$ As CC and LC have similar clinical presentations and share histopathological features, except for the subepithelial collagen band in $\mathrm{CC}$, it has been discussed whether CC and LC are actually the same disease seen in different phases of development. Conversion of $\mathrm{CC}$ to $\mathrm{LC}$ or the reverse has been reported, but is rare. ${ }^{3}$ In clinical practice, however, management or therapy is not influenced by histological type.

\section{Genetics}

It is doubtful whether there is a genetic predisposition to MC. Familial cases have been reported, but it is uncertain whether these reflect random associations or shared familial traits. ${ }^{28,61-64}$ An association was reported between MC and $H L A-D Q 2$ or $D Q 1,3$, and the $H L A-D R 3-D Q 2$ haplotype, as well as with $T N F 2$-allele carriage, irrespective of the presence of concomitant celiac disease. ${ }^{65,66}$ Variants of the MMP9 gene have been reported to be associated with $\mathrm{CC},{ }^{67}$ but no association with NOD2/CARD15 polymorphisms and susceptibility to $\mathrm{CC}$ has been found. ${ }^{68}$

\section{Mucosal immunopathology}

Ulcerative colitis and Crohn's disease are considered driven by aberrant $\mathrm{CD} 4^{+}$T-lymphocyte responses. ${ }^{69,70}$ In contrast, $\mathrm{MC}$ presents with heavy infiltration of $\mathrm{CD}^{+}$IELs. $^{71-74}$ Using immunohistochemistry, a significant increase in the amount of $\mathrm{CD}^{+} \mathrm{T}$ lymphocytes was found in the epithelium in both LC and CC patients compared to controls, with the most pronounced increase found in LC. In contrast, the amount of $\mathrm{CD}^{+} \mathrm{T}$ cells was markedly reduced in the lamina propria of both LC and CC patients compared to controls. ${ }^{73}$ The expression of the activation/memory marker CD45RO, found on $\mathrm{CD}^{+}$as well as $\mathrm{CD} 8^{+} \mathrm{T}$ cells, and the transcription factor Foxp3, involved in differentiation of $\mathrm{CD}^{+}$and $\mathrm{CD}^{+}$ regulatory $\mathrm{T}$ cells $\left(\mathrm{T}_{\text {regs }}\right)$, was more abundant in lymphocytes in the epithelium, as well as in the lamina propria of both LC and CC compared to controls. Also Ki67, a proliferation marker, was significantly increased in IELs of both CC and LC patients compared to controls. Double-staining for these markers together with CD4 or CD8 was however not performed.

These findings were corroborated by multicolor flow-cytometric analysis of isolated IELs and lamina propria lymphocytes, demonstrating increased proportions of $\mathrm{CD}^{+}$ and $\mathrm{CD}^{+}$colonic lymphocytes expressing CD45RO and Ki67, albeit to different degrees. ${ }^{74}$ Within the $\mathrm{CD} 8^{+}$IEL population, the proportion of $\mathrm{CD}_{4} 5 \mathrm{RO}^{+}$cells showed a trend toward a significant increase in patients with $\mathrm{CC}$, but not LC. The $\mathrm{CD}^{+}$IELs also demonstrated a significantly enhanced proportion of $\mathrm{Ki} 67^{+}$cells in $\mathrm{CC}$, but not LC patients. ${ }^{74}$ In contrast, no significant changes in the proportions of these populations were found within the $\mathrm{CD} 4^{+}$IELs. Within the lamina propria, the proportions of $\mathrm{CD}^{+}$as well as $\mathrm{CD}^{+}$ $\mathrm{T}$ cells expressing CD45RO or Ki67 were both increased in $\mathrm{CC}$ patients, with a trend toward significant increases in $\mathrm{LC}$ patients, except the proportions of $\mathrm{Ki} 67^{+} \mathrm{CD} 4^{+}$ lamina propria $\mathrm{T}$ cells, which were significantly enhanced 
also in LC patients. ${ }^{74}$ Furthermore, increased proportions of $\mathrm{CD} 4{ }^{+} 8^{+}$double-positive IELs were seen in $\mathrm{CC}$, and a trend toward increased proportions in $\mathrm{LC}$, as well as in lamina propria lymphocytes in both CC and LC. These cells likewise displayed higher expression of CD45RO. ${ }^{74}$ In contrast to the changes seen in the T-cell populations, no changes were recorded in the proportion of B cells or plasma cells. ${ }^{74}$ In contrast to ulcerative colitis, ${ }^{75}$ both $\mathrm{CC}$ and LC had lower levels of $\mathrm{T}$ cell receptor excision circles (TRECs) in the colonic mucosa compared to controls. ${ }^{76}$ This suggests that the increased numbers of T cells in the inflamed mucosa of MC patients is due to expansion of local resident $\mathrm{T}$ lymphocytes rather than recruitment of recent thymic emigrants to the colonic mucosa. The expression of different chemokines and their corresponding chemokine receptors has been elucidated, and is currently being submitted for publication (Günaltay and Hultgren Hörnquist et al, unpublished data).

These immunologic data support the view that $\mathrm{MC}$ is caused by an aberrant immune response to one or several (yet to be identified) luminal agent(s) in susceptible individuals. ${ }^{73,74}$ This view is furthermore supported by the clinical observation that fecal stream diversion by an ileostomy reduced the characteristic histopathologic changes of $\mathrm{CC}$, which recurred after closure of the ileostomy. ${ }^{77}$

Analyses of different T-helper (Th)-1/Th2/Th17 and cytotoxic $\mathrm{T}$ (Tc)-1/Tc2/Tc17 cell-associated cytokines and transcription factors showed that levels of IFN- $\gamma$, IL-12, IL-1 $\beta$, IL-6, IL-17A, IL-21, IL-22, IL-23, and TNF were upregulated in the inflamed mucosa of $\mathrm{MC}$ patients compared to controls indicating a mixed Th17/Tc17 and Th1/Tc1 mucosal cytokine profile. ${ }^{78}$ Others found a Th1 mucosal cytokine profile with IFN- $\gamma, \mathrm{TNF} \alpha$, and IL-15 as the predominantly upregulated cytokines. ${ }^{79}$ As these studies were performed on whole biopsies rather than sorted $\mathrm{T}$ lymphocytes, the production of cytokines from nonlymphoid cells, eg, colonic epithelial cells, macrophages, neutrophils, and dendritic cells, cannot be excluded.

In addition to changes in adaptive immune responses, we recently demonstrated changes in innate immune responses, as expression of IL-1 receptor-associated kinase $\mathrm{M}$ (suppressing Toll-like receptor signaling), micro-ribonucleic acid (miRNA)-21 and -146a (both curbing inflammation), as well as miRNA-155 (promoting inflammation), were increased, whereas expression of IL-37 (inhibiting innate immunity) was decreased in $\mathrm{MC}$ patients compared to controls. The expression pattern was different between $\mathrm{CC}$ and LC, further supporting the hypothesis that CC and LC are two different entities. ${ }^{80}$
Increased luminal levels of bFGF, ECP, and VEGF were reported in $\mathrm{CC},{ }^{81-83}$ whereas others verified increased mucosal levels of VEGF that were not affected by budesonide therapy. ${ }^{84}$ Others reported increased numbers of activated eosinophils in the colonic mucosa in CC patients, which were normalized after budesonide treatment. ${ }^{40}$ An imbalance of collagen turnover, either an increased synthesis or reduced degradation, may explain the increased subepithelial collagen layer in CC. ${ }^{28}$ Findings of an increased number and activity of myofibroblasts may support an increased collagen synthesis. ${ }^{85}$ Among degrading enzymes, matrix metalloproteinases (MMPs) have a central role that is regulated by endogenous tissue inhibitors of metalloproteinases (TIMPs). ${ }^{86}$ Impaired collagen degradation in CC was suggested by findings of restricted MMP-1 RNA expression and increased TIMP expression. ${ }^{87}$

Colonic nitric oxide production is greatly increased in active $\mathrm{CC}$ and LC, caused by an upregulation of inducible nitric oxide synthase in the colonic epithelium. ${ }^{88-91}$ Support for nitric oxide being involved in the pathogenesis of CC comes from clinical trials. In contrast to placebo, treatment with budesonide resulted in a significant reduction in inducible nitric oxide synthase messenger RNA that correlated with clinical and histopathological improvement. ${ }^{92}$

Epithelial barrier function has been reported to be abnormal. Increased paracellular and transcellular mucosal permeability were found in patients with $\mathrm{CC}$ that persisted after therapy with budesonide..$^{93,94}$

\section{Infection or autoimmunity}

An infectious cause has been suspected in patients with a sudden presentation of disease. Onset of MC after enteric infections with Yersinia enterocolitica, Campylobacter jejuni, or Clostridium difficile has occasionally been reported. ${ }^{95-98}$ Furthermore, a seasonal pattern of onset of LC may support an infectious cause. ${ }^{18,99}$ However, stool cultures are negative in most cases of $\mathrm{MC}$ with an acute onset.

Concomitant autoimmune diseases are common, and seen in up to $30 \%-50 \%$ of patients with $\mathrm{MC}$. The most common are celiac disease $(2 \%-20 \%)$, thyroid disease $(10 \%-20 \%)$, and other autoimmune conditions, such as diabetes mellitus, arthritis, and Sjögren's syndrome, whereas association with autoimmune liver disease has not been reported, in contrast to ulcerative colitis and Crohn's disease. However, a diagnostic autoantibody has not yet been identified. In many cases, the diagnosis of associated autoimmune disease precedes that of MC. ${ }^{100}$ It is important to be aware of these associations in clinical practice. If the patient with $\mathrm{MC}$ does not respond 
to treatment, a concomitant autoimmune disease, especially celiac disease, should be ruled out. Likewise, MC should be considered in the patient with an autoimmune disease who develops nonbloody, watery diarrhea.

The finding of increased Foxp3 expression in MC may in the light of this seem paradoxical. Increased frequencies of Foxp3 $3^{+} \mathrm{CD}^{+} \mathrm{T}_{\text {regs }}$ have also been reported in Crohn's disease and ulcerative colitis. ${ }^{101}$ We have demonstrated in a mouse model of colitis that whereas the suppressive function of FoxP3 ${ }^{+} \mathrm{T}_{\text {regs }}$ was similar between wild-type mice and mice with colitis, $\mathrm{CD}^{+}$effector $\mathrm{T}$ cells from colitic mice were much less suppressed by $\mathrm{T}_{\text {regs }}$ irrespective of if they were derived from colitic or wild-type mice. ${ }^{102}$ Therefore, the problems seemed to be confined to the effector $\mathrm{T}$ cells being resistant to $\mathrm{T}_{\text {reg }}$-mediated suppression.

\section{Smoking, drugs}

Of environmental factors, smoking is the best-documented risk factor for $\mathrm{MC}$. Three studies have consistently shown that smoking is associated with both CC and LC. ${ }^{103-105}$ Smokers developed their disease $>10$ years earlier than nonsmokers, but smoking did not influence subsequent disease course. ${ }^{104,106}$

There are several reports of drug-induced MC and a strong likelihood of association has been found with acarbose, aspirin, Cyclo3 Fort, nonsteroidal anti-inflammatory drugs, proton-pump inhibitors, ranitidine, sertraline, and ticlopidine. ${ }^{103,107}$ Assessment of concomitant drug use in patients with $\mathrm{MC}$ is thus important to identify, and withdrawal of drugs considered that might cause or worsen the condition. ${ }^{2,28}$ However, confounding by indication may explain some of the reported associations, and further studies are required.

\section{Therapy}

No curative therapy currently exists for MC. The primary goals of medical therapy are to achieve and maintain clinical remission and to improve the patient's quality of life. Whether histological remission is an essential objective is currently unknown. Consideration of concomitant drug use, smoking, and dietary factors, such as excess use of caffeine, alcohol, and dairy products that might worsen the condition, is important. Concomitant celiac disease or bile-acid malabsorption should be considered. ${ }^{28}$

Based on currently available evidence, an algorithm for the treatment of $\mathrm{MC}$ was proposed by the European $\mathrm{MC}$ Group (http://www.emcg-ibd.eu) (Figure 2). ${ }^{3}$ The algorithm is slightly modified herein, due to recent negative data on mesalazine. ${ }^{108}$ The evidence for this proposal is delineated in the following sections.

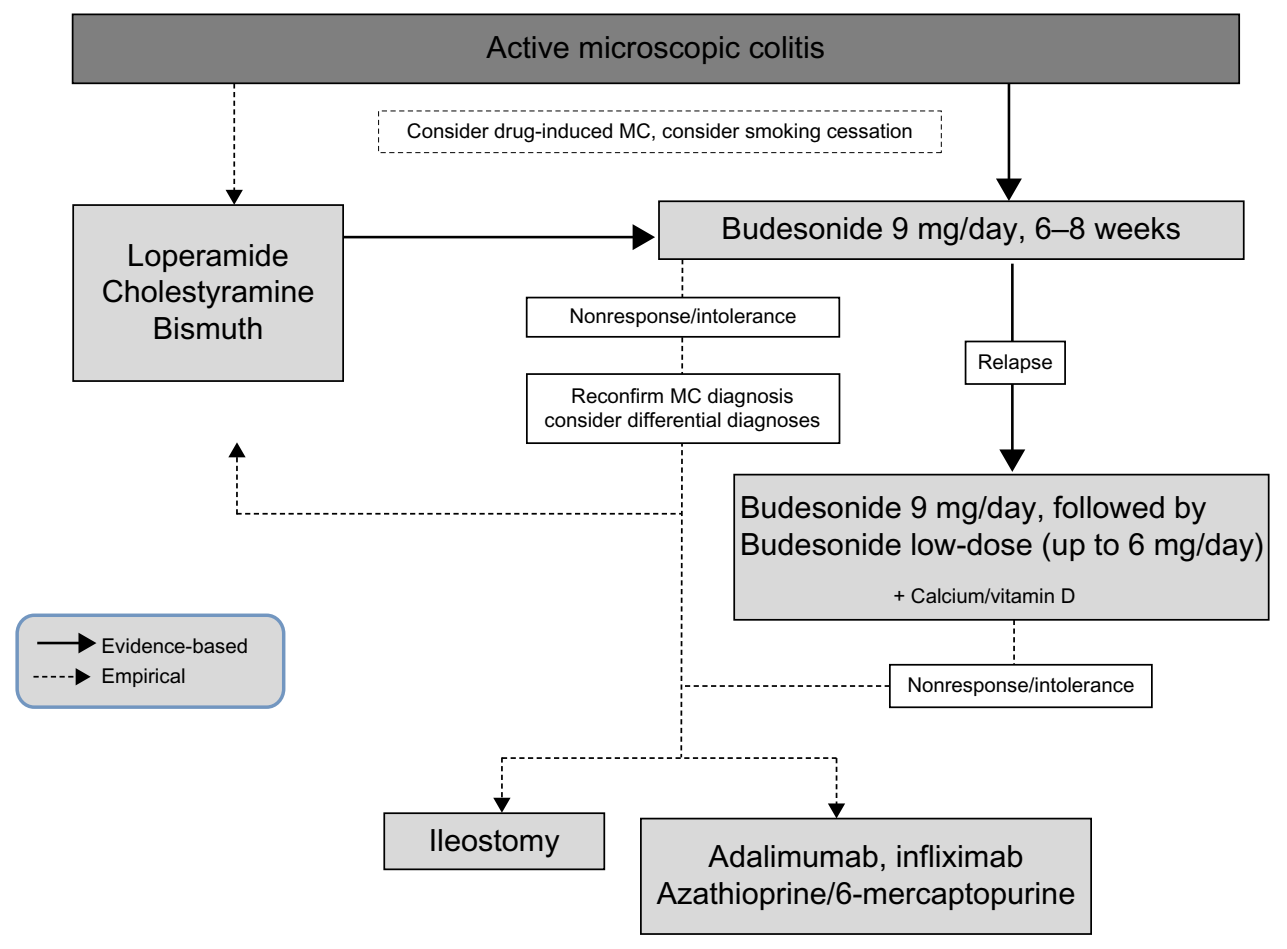

Figure 2 Algorithm for the treatment of microscopic colitis proposed by the European Microscopic Colitis Group. ${ }^{3}$

Note: Reprinted with permission from Elsevier: (C) 2012 Reproduced from Münch A, Aust D, Bohr J, et al. Microscopic colitis: current status, present and future challenges: statements of the European Microscopic Colitis Group. J Crohns Colitis. 2012;6(9):932-945. ${ }^{3}$

Abbreviation: MC, microscopic colitis. 


\section{Antidiarrheals}

Loperamide or cholestyramine, albeit not properly studied in randomized placebo-controlled trials, are often recommended as the first treatment alternative in patients with mild symptoms. ${ }^{2,3,28}$ Clinical experience suggests a symptomatic response in a proportion of patients, mainly in those with mild symptoms. Cholestyramine has a specific indication in patients with concomitant bile-acid malabsorption. However, sustained clinical remission is rarely achieved, and an impact on colonic inflammation is unlikely.

\section{Budesonide}

Budesonide, a locally active corticosteroid with extensive first-pass metabolism in the liver and low systemic exposure, is currently the best-documented treatment. ${ }^{109,110}$ It significantly improves clinical symptoms and the patient's quality of life. Three short-term, randomized controlled trials in $\mathrm{CC}$ have consistently shown that budesonide $9 \mathrm{mg}$ daily for 6-8 weeks is superior to placebo. ${ }^{111-113}$ About $80 \%$ of patients responded to budesonide usually after $2-4$ weeks of treatment. In a Cochrane meta-analysis, the pooled odds ratio for clinical response with budesonide was 12.32 (95\% confidence interval [CI] 5.53-27.46) compared to placebo, and the number needed to treat was two patients. ${ }^{110}$ Similarly, in a placebo-controlled trial of LC, ${ }^{114}$ budesonide was superior to placebo: 18 of 21 patients $(86 \%, 95 \%$ CI 65\%-96\%) in the budesonide group achieved a clinical response after 6 weeks compared to eight of 20 patients $(40 \%, 95 \%$ CI $22 \%-61 \%)$ in the placebo group, yielding an odds ratio of 9.00 (95\% CI 1.98-40.93, $P=0.004) .{ }^{109}$

The relapse rate is high after withdrawal of successful short-term budesonide therapy in CC, and $60 \%-80 \%$ of patients will have an early recurrence of symptoms. ${ }^{111-113}$ For that reason, there is a need for effective and safe maintenance therapy. Two studies have proven that budesonide $6 \mathrm{mg} / \mathrm{day}$ for 6 months is well tolerated and superior to placebo. ${ }^{115,116}$ Eighty patients who had responded to open-label budesonide were randomized to treatment with budesonide $6 \mathrm{mg} /$ day or placebo for 6 months. Clinical response was maintained in 33 of $40(83 \%)$ patients who received budesonide compared to eleven of $40(28 \%)$ patients given placebo $(P=0.0002)$. The pooled odds ratio for maintenance of clinical response with budesonide compared to placebo was $8.40(95 \% \mathrm{CI}$ 2.73-25.81) with a number needed to treat of two patients. Histological response was seen in $48 \%$ of patients treated with budesonide compared to $15 \%$ of patients in the placebo group $(P=0.002) \cdot{ }^{110}$ However, 6-month maintenance therapy did not change the following disease course, as the relapse risk after withdrawal of 24 weeks' maintenance treatment was similar to that observed after 6 weeks' induction therapy, and the median time to clinical relapse was equal in the two groups (39 days versus 38 days). ${ }^{115} \mathrm{~A}$ high stool frequency (more than five per day) at baseline and a long duration of diarrhea (>12 months) are risk factors for clinical relapse after withdrawal of short-term budesonide therapy in CC. ${ }^{117}$ In a recent randomized controlled trial, an even-lower dose of budesonide of $4.5 \mathrm{mg} /$ day was found to be superior to placebo (clinical remission 61.4\% versus 16.7\%) during 12 months' maintenance therapy. ${ }^{118}$ Although not formally proven, maintenance treatment with low doses of budesonide of $3 \mathrm{mg}$ /day or $3 \mathrm{mg}$ every other day have been reported efficacious and may be safely used in the long term. ${ }^{28}$

\section{Prednisolone}

Prednisolone has a limited place in the treatment of MC. Although no formal comparative trials are available, it is associated with more frequent side effects, and its efficacy seems inferior to budesonide. ${ }^{119,120}$

\section{Aminosalicylates}

Sulfasalazine and mesalazine have previously been used in $\mathrm{MC}$, but not until recently strictly evaluated in controlled trials. ${ }^{28}$ In a study by Calabrese et al, 64 patients with MC were randomized to 6 months' treatment with mesalazine $2.4 \mathrm{~g} /$ day or mesalazine $2.4 \mathrm{~g} /$ day + cholestyramine $4 \mathrm{~g} /$ day . A high remission rate was seen in both treatment arms, and $85 \%$ of patients with LC and $91 \%$ of patients with CC were in remission at the end of study. ${ }^{121}$ In the first placebo-controlled randomized trial, mesalazine $3 \mathrm{~g}$ /day was ineffective and no better than placebo as short-term induction treatment for 8 weeks. ${ }^{108}$

\section{Antibiotics, probiotics, Boswellia serrata}

Antibiotics, such as metronidazole or erythromycin, have previously been used, but there are no controlled data. ${ }^{18,29}$ Treatment with probiotics shows uncertain results and needs further evaluation. ${ }^{122}$ Boswellia serrata extract has been evaluated in a placebo-controlled trial, showing a nonsignificant trend in favor of active treatment. ${ }^{123}$

\section{Thiopurines, methotrexate, and anti-TNF therapy}

In patients not responding to budesonide or other treatment alternatives, immunosuppressive therapy may be carefully considered, although the evidence is virtually absent. ${ }^{2,3,28}$ In an open study, azathioprine induced partial or complete remission 
in eight of nine patients with MC. ${ }^{124}$ In a retrospective series, the overall response rate to thiopurines was 19 of 46 (41\%), but azathioprine was accompanied by a high frequency of side effects, leading to withdrawal of therapy. ${ }^{125}$ There are conflicting data on the efficacy of methotrexate. Of 19 patients with CC treated with methotrexate orally (5-25 mg/week, median 7.5-10 mg/week), a good response, generally within 2-3 weeks of treatment, was seen in 14 patients, and a partial response in two patients. ${ }^{126}$ Others reported opposing data in nine patients with CC refractory to budesonide treatment. After 12 weeks of treatment with methotrexate 15-25 mg/week subcutaneously, no patient improved. ${ }^{127}$ Infliximab or adalimumab have been used in a few selected MC patients failing other treatment alternatives. ${ }^{128-131}$ Currently, these preliminary data do not allow any conclusions or recommendations on the use of anti-TNFs in refractory $\mathrm{MC}$. The frequency of therapy-refractory disease is unknown, but was estimated to be $1.3 \%$ of all cases with MC. ${ }^{129}$ The best therapeutic alternative for these patients, who may suffer from incapacitating bowel symptoms, is thus an important target for future studies.

\section{Bismuth subsalicylate}

Bismuth subsalicylate has been shown to be effective in a small placebo-controlled study, not yet fully published, of nine patients with CC and five with LC. ${ }^{132}$ The drug is not accessible in a number of countries because of concerns regarding drug toxicity.

\section{Surgery}

Surgical therapy may be considered for patients with severe, unresponsive MC. Both split ileostomy and subtotal colectomy have been performed and reported to be successful. ${ }^{77,133}$ The indication for surgical therapy today is limited, considering the improvement of medical therapy. ${ }^{2,3,28}$

\section{Health-related quality of life}

MC may be considered a milder disease than ulcerative colitis or Crohn's disease, in view of the absence of overt mucosal inflammation, ulcerations, and systemic inflammation. Therefore, the influence of active MC on HRQoL was previously underestimated or not recognized. However, there has been an increasing interest in this area. In a Swedish cross-sectional study, patients with active CC had impaired HRQoL compared with patients with inactive disease, and with a Swedish background population. ${ }^{134}$ The impact on HRQoL was independently and mainly associated with severity of clinical symptoms. Patients with three or more stools/day or one or more watery stools/day had impaired HRQoL compared to those with fewer than three stools/day and no watery stools/ day. ${ }^{135}$ These cutoff levels may be used in clinical practice or clinical trials to define disease activity and clinical remission, respectively. In clinical trials, budesonide has been shown to improve HRQoL, ${ }^{136}$ and Swedish patients in clinical remission had an HRQoL similar to a Swedish background population. Corresponding results have recently been reported in patients with LC: disease activity impaired HRQoL, whereas no difference was seen in patients in clinical remission compared to matched controls. ${ }^{34}$

\section{Conclusion and future aspects}

$\mathrm{MC}$ is a common cause of chronic diarrhea, especially among elderly patients. A correct diagnosis depends on awareness of the disease among general practitioners (to refer the patient with chronic diarrhea for a colonoscopy), endoscopists (to obtain adequate biopsies at pancolonoscopy although the colonic mucosa is normal), and pathologists (to recognize features of $\mathrm{MC}$ ). There is a need for biomarkers to aid the diagnosis and to monitor disease activity during follow-up. Environmental factors need to be explored in future epidemiologic studies, and large-scale genetic studies are warranted to identify susceptibility genes associated with MC. A deeper understanding of the underlying pathophysiology and mucosal immunopathology is necessary, aimed at developing new treatment alternatives. Currently, budesonide is the only evidence-based effective therapy. However, for patients intolerant of or not responding to budesonide, we lack well-documented effective alternatives.

\section{Acknowledgments}

Our studies of microscopic colitis were supported by the Örebro County Research Committee, Örebro University Hospital Research Foundation (Nyckelfonden), the Research Council Sweden (VR) (Grant no 2008-4075), and the Swedish Society of Medicine (Bengt Ihre Foundation).

\section{Disclosure}

JB has served as a speaker for Dr Falk Pharma, Tillotts Pharma. NN has served as a speaker for MSD. CT has served as a speaker for Dr Falk Pharma, Tillotts Pharma, Ferring, MSD, and AstraZeneca. The other authors report no conflicts of interest in this work.

\section{References}

1. Nyhlin N, Bohr J, Eriksson S, Tysk C. Systematic review: microscopic colitis. Aliment Pharmacol Ther. 2006;23(11):1525-1534.

2. Pardi DS, Kelly CP. Microscopic colitis. Gastroenterology. 2011;140(4): 1155-1165. 
3. Münch A, Aust D, Bohr J, et al. Microscopic colitis: current status, present and future challenges: statements of the European Microscopic Colitis Group. J Crohns Colitis. 2012;6(9):932-945.

4. Lindström CG. 'Collagenous colitis' with watery diarrhoea - a new entity? Pathol Eur. 1976;11(1):87-89.

5. Freeman H, Weinstein WM, Shnitka T, Wensel RH, Sartor VE. Watery diarrhea syndrome associated with a lesion of the colonic basement membrane-lamina propria interface. Ann Royal Coll Phys Surg Can. 1976;9:A45.

6. Lazenby AJ, Yardley JH, Giardiello FM, Jessurun J, Bayless TM. Lymphocytic ("microscopic") colitis: a comparative histopathologic study with particular reference to collagenous colitis. Hum Pathol. 1989;20(1):18-28.

7. Fekih M, Ben Hriz F, Sassi A, Matri S, Filali A, Boubaker J. [Microscopic colitis. A 20 cases series]. Tunis Med. 2006;84(7): 403-406. French.

8. Garg PK, Singh J, Dhali GK, Mathur M, Sharma MP. Microscopic colitis is a cause of large bowel diarrhea in Northern India. J Clin Gastroenterol. 1996;22(1):11-15.

9. Rubio-Tapia A, Martinez-Salgado J, García-Leiva J, Martinez-Benítez B, Uribe M. Microscopic colitides: a single center experience in Mexico. Int J Colorectal Dis. 2007;22(9):1031-1036.

10. Park YS, Baek DH, Kim WH, et al. Clinical characteristics of microscopic colitis in Korea: prospective multicenter study by KASID Gut Liver. 2011;5(2):181-186.

11. Bohr J, Tysk C, Eriksson S, Järnerot G. Collagenous colitis in Örebro, Sweden, an epidemiological study 1984-1993. Gut. 1995;37(3): 394-397.

12. Olesen M, Eriksson S, Bohr J, Jarnerot G, Tysk C. Microscopic colitis a common diarrhoeal disease. An epidemiological study in Örebro, Sweden, 1993-1998. Gut. 2004;53(3):346-350.

13. Wickbom A, Bohr J, Eriksson S, Udumyan R, Nyhlin N, Tysk C. Stable incidence of collagenous colitis and lymphocytic colitis in Örebro, Sweden, 1999-2008: a continuous epidemiological study. Inflamm Bowel Dis. 2013;19(11):2387-2393.

14. Pardi DS, Loftus EV Jr, Smyrk TC, et al. The epidemiology of microscopic colitis: a population based study in Olmsted County, Minnesota. Gut. 2007;56(4):504-508.

15. Gentile NM, Khanna S, Loftus EV Jr, et al. The epidemiology of microscopic colitis in Olmsted County from 2002 to 2010: a populationbased study. Clin Gastroenterol Hepatol. 2014;12(5):838-842.

16. Benchimol EI, Kirsch R, Viero S, Griffiths AM. Collagenous colitis and eosinophilic gastritis in a 4-year old girl: a case report and review of the literature. Acta Paediatr. 2007;96(9):1365-1367.

17. Camarero C, Leon F, Colino E, et al. Collagenous colitis in children: clinicopathologic, microbiologic, and immunologic features. J Pediatr Gastroenterol Nutr. 2003;37(4):508-513.

18. Olesen M, Eriksson S, Bohr J, Jarnerot G, Tysk C. Lymphocytic colitis: a retrospective clinical study of 199 Swedish patients. Gut 2004;53(4):536-541.

19. Williams JJ, Kaplan GG, Makhija S, et al. Microscopic colitis-defining incidence rates and risk factors: a population-based study. Clin Gastroenterol Hepatol. 2008;6(1):35-40.

20. Stewart M, Andrews CN, Urbanski S, Beck PL, Storr M. The association of coeliac disease and microscopic colitis: a large population-based study. Aliment Pharmacol Ther. 2011;33(12):1340-1349.

21. Fernández-Bañares F, Salas A, Forné M, Esteve M, Espinós J, Viver JM. Incidence of collagenous and lymphocytic colitis: a 5-year populationbased study. Am J Gastroenterol. 1999;94(2):418-423.

22. Fernández-Bañares F, Salas A, Esteve M, et al. Evolution of the incidence of collagenous colitis and lymphocytic colitis in Terrassa, Spain: a population-based study. Inflamm Bowel Dis. 2011;17(4):1015-1020.

23. Agnarsdottir M, Gunnlaugsson O, Orvar KB, et al. Collagenous and lymphocytic colitis in Iceland. Dig Dis Sci. 2002;47(5):1122-1128.

24. Bjørnbak C, Engel PJ, Nielsen PL, Munck LK. Microscopic colitis: clinical findings, topography and persistence of histopathological subgroups. Aliment Pharmacol Ther. 2011;34(10):1225-1234.
25. Vigren L, Olesen M, Benoni C, Sjöberg K. An epidemiological study of collagenous colitis in southern Sweden from 2001-2010. World J Gastroenterol. 2012;18(22):2821-2826.

26. Guagnozzi D, Lucendo AJ, Angueira-Lapeña T, González-Castillo S, Tenias Burillo JM. Prevalence and incidence of microscopic colitis in patients with diarrhoea of unknown aetiology in a region in central Spain. Dig Liver Dis. 2012;44(5):384-388.

27. Thörn M, Sjöberg D, Ekbom A, et al. Microscopic colitis in Uppsala health region, a population-based prospective study 2005-2009. Scand J Gastroenterol. 2013;48(7):825-830.

28. Tysk C, Wickbom A, Nyhlin N, Eriksson S, Bohr J. Recent advances in diagnosis and treatment of microscopic colitis. Ann Gastroenterol. 2011;24(4):253-262.

29. Bohr J, Tysk C, Eriksson S, Abrahamsson H, Järnerot G. Collagenous colitis: a retrospective study of clinical presentation and treatment in 163 patients. Gut. 1996;39(96):846-851.

30. Bohr J, Larsson LG, Eriksson S, Järnerot G, Tysk C. Colonic perforation in collagenous colitis: an unusual complication. Eur J Gastroenterol Hepatol. 2005;17(1):121-124

31. Allende DS, Taylor SL, Bronner MP. Colonic perforation as a complication of collagenous colitis in a series of 12 patients. Am J Gastroenterol. 2008;103(10):2598-2604.

32. Abboud R, Pardi DS, Tremaine WJ, Kammer PP, Sandborn WJ Loftus EV Jr. Symptomatic overlap between microscopic colitis and irritable bowel syndrome: a prospective study. Inflamm Bowel Dis. 2013;19(3):550-553.

33. Limsui D, Pardi DS, Camilleri M, et al. Symptomatic overlap between irritable bowel syndrome and microscopic colitis. Inflamm Bowel Dis. 2007;13(2):175-181.

34. Nyhlin N, Wickbom A, Montgomery SM, Tysk C, Bohr J. Long-term symptom burden and health-related quality of life in patients with collagenous and lymphocytic colitis; a case-control study. Aliment Pharmacol Ther. 2014;39(9):963-972.

35. Halpin SJ, Ford AC. Prevalence of symptoms meeting criteria for irritable bowel syndrome in inflammatory bowel disease: systematic review and meta-analysis. Am J Gastroenterol. 2012;107(10):1474-1482.

36. Fernandez-Bañares F, Esteve M, Salas A, et al. Bile acid malabsorption in microscopic colitis and in previously unexplained functional chronic diarrhea. Dig Dis Sci. 2001;46(10):2231-2238.

37. Ung KA, Gillberg R, Kilander A, Abrahamsson H. Role of bile acids and bile acid binding agents in patients with collagenous colitis. Gut. 2000;46(2):170-175.

38. Ung KA, Kilander A, Willen R, Abrahamsson H. Role of bile acids in lymphocytic colitis. Hepatogastroenterology. 2002;49(44):432-437.

39. Wildt S, Nordgaard-Lassen I, Bendtsen F, Rumessen JJ. Metabolic and inflammatory faecal markers in collagenous colitis. Eur J Gastroenterol Hepatol. 2007;19(7):567-574.

40. Wagner M, Lampinen M, Sangfelt P, Agnarsdottir M, Carlson M. Budesonide treatment of patients with collagenous colitis restores normal eosinophil and T-cell activity in the colon. Inflamm Bowel Dis. 2010;16(7):1118-1126.

41. Wagner M, Peterson CG, Stolt I, et al. Fecal eosinophil cationic protein as a marker of active disease and treatment outcome in collagenous colitis: a pilot study. Scand J Gastroenterol. 2011;46(7-8):849-854.

42. Wagner M, Stridsberg M, Peterson CG, Sangfelt P, Lampinen M, Carlson M. Increased fecal levels of chromogranin A, chromogranin B, and secretoneurin in collagenous colitis. Inflammation. 2013;36(4): 855-861.

43. Cruz-Correa M, Milligan F, Giardiello FM, et al. Collagenous colitis with mucosal tears on endoscopic insufflation: a unique presentation. Gut. 2002;51(4):600.

44. Sherman A, Ackert JJ, Rajapaksa R, West AB, Oweity T. Fractured colon: an endoscopically distinctive lesion associated with colonic perforation following colonoscopy in patients with collagenous colitis J Clin Gastroenterol. 2004;38(4):341-345.

45. Wickbom A, Lindqvist M, Bohr J, et al. Colonic mucosal tears in collagenous colitis. Scand J Gastroenterol. 2006;41(6):726-729. 
46. Kiesslich R, Hoffman A, Goetz M, et al. In vivo diagnosis of collagenous colitis by confocal endomicroscopy. Gut. 2006;55(4):591-592.

47. Meining A, Schwendy S, Becker V, Schmid RM, Prinz C. In vivo histopathology of lymphocytic colitis. Gastrointest Endosc. 2007;66(2):398-399.

48. Zambelli A, Villanacci V, Buscarini E, Bassotti G, Albarello L. Collagenous colitis: a case series with confocal laser microscopy and histology correlation. Endoscopy. 2008;40(7):606-608.

49. Magro F, Langner C, Driessen A, et al. European consensus on the histopathology of inflammatory bowel disease. J Crohns Colitis. 2013;7(10):827-851.

50. Münch A, Langner C. Microscopic colitis: clinical and pathologic perspectives. Clin Gastroenterol Hepatol. Epub January 7, 2014.

51. Aust D, Münch A, Olesen M, et al. Topographical distribution of collagenous colitis - a pooled histological analysis of 2 European prospective multicenter trials. Gastroenterology. 2013;144 Suppl 1:S421.

52. Warren BF, Edwards CM, Travis SP. 'Microscopic colitis': classification and terminology. Histopathology. 2002;40(4):374-376.

53. Goldstein NS, Bhanot P. Paucicellular and asymptomatic lymphocytic colitis: expanding the clinicopathologic spectrum of lymphocytic colitis. Am J Clin Pathol. 2004;122(3):405-411.

54. Fernández-Bañares F, Casalots J, Salas A, et al. Paucicellular lymphocytic colitis: is it a minor form of lymphocytic colitis? A clinical pathological and immunological study. Am J Gastroenterol. 2009;104(5):1189-1198.

55. Libbrecht L, Croes R, Ectors N, Staels F, Geboes K. Microscopic colitis with giant cells. Histopathology. 2002;40(4):335-338.

56. Sandmeier D, Bouzourene H. Microscopic colitis with giant cells: a rare new histopathologic subtype? Int J Surg Pathol. 2004;12(1):45-48.

57. Yuan S, Reyes V, Bronner MP. Pseudomembranous collagenous colitis. Am J Surg Pathol. 2003;27(10):1375-1379.

58. Rubio CA, Lindholm J. Cryptal lymphocytic coloproctitis: a new phenotype of lymphocytic colitis? J Clin Pathol. 2002;55(2): $138-140$.

59. Saurine TJ, Brewer JM, Eckstein RP. Microscopic colitis with granulomatous inflammation. Histopathology. 2004;45(1):82-86.

60. Chang F, Deere H, Vu C. Atypical forms of microscopic colitis: morphological features and review of the literature. Adv Anat Pathol. 2005;12(4):203-211.

61. Abdo AA, Zetler PJ, Halparin LS. Familial microscopic colitis. Can $J$ Gastroenterol. 2001;15(5):341-343.

62. Freeman HJ. Familial occurrence of lymphocytic colitis. Can J Gastroenterol. 2001;15(11):757-760.

63. Järnerot G, Hertervig E, Grännö C, et al. Familial occurrence of microscopic colitis: a report on five families. Scand J Gastroenterol. 2001;36(9):959-962.

64. van Tilburg AJ, Lam HG, Seldenrijk CA, et al. Familial occurrence of collagenous colitis. A report of two families. J Clin Gastroenterol. 1990;12(3):279-285.

65. Fine KD, Do K, Schulte K, et al. High prevalence of celiac sprue-like HLA-DQ genes and enteropathy in patients with the microscopic colitis syndrome. Am J Gastroenterol. 2000;95(8):1974-1982.

66. Koskela RM, Karttunen TJ, Niemelä SE, Lehtola JK, Ilonen J, Karttunen RA. Human leucocyte antigen and TNF $\alpha$ polymorphism association in microscopic colitis. Eur $J$ Gastroenterol Hepatol. 2008;20(4):276-282.

67. Madisch A, Hellmig S, Schreiber S, Bethke B, Stolte M, Miehlke S. Allelic variation of the matrix metalloproteinase-9 gene is associated with collagenous colitis. Inflamm Bowel Dis. 2011;17(11): 2295-2298.

68. Madisch A, Hellmig S, Schreiber S, Bethke B, Stolte M, Miehlke S. NOD2/CARD15 gene polymorphisms are not associated with collagenous colitis. Int J Colorectal Dis. 2007;22(4):425-428.

69. Abraham C, Cho JH. Inflammatory bowel disease. $N$ Engl J Med. 2009;361(21):2066-2078.

70. Xavier RJ, Podolsky DK. Unravelling the pathogenesis of inflammatory bowel disease. Nature. 2007;448(7152):427-434.
71. Armes J, Gee DC, Macrae FA, Schroeder W, Bhathal PS. Collagenous colitis: jejunal and colorectal pathology. J Clin Pathol. 1992;45(9): 784-787.

72. Mosnier JF, Larvol L, Barge J, et al. Lymphocytic and collagenous colitis: an immunohistochemical study. Am J Gastroenterol. 1996;91(4): 709-713.

73. Göranzon C, Kumawat AK, Hultgren-Hörnqvist E, et al. Immunohistochemical characterization of lymphocytes in microscopic colitis. J Crohns Colitis. 2013;7(10):e434-e442.

74. Kumawat AK, Strid H, Elgbratt K, Tysk C, Bohr J, Hultgren Hörnquist E. Microscopic colitis patients have increased proportions of Ki67(+) proliferating and $\mathrm{CD} 45 \mathrm{RO}(+)$ active/memory $\mathrm{CD} 8(+)$ and CD4(+)8(+) mucosal T cells. J Crohns Colitis. 2013;7(9):694-705.

75. Elgbratt K, Kurlberg G, Hahn-Zohric M, Hörnquist EH. Rapid migration of thymic emigrants to the colonic mucosa in ulcerative colitis patients. Clin Exp Immunol. 2010;162(2):325-336.

76. Kumawat AK, Elgbratt K, Tysk C, Bohr J, Hörnquist EH. Reduced $\mathrm{T}$ cell receptor excision circle levels in the colonic mucosa of microscopic colitis patients indicate local proliferation rather than homing of peripheral lymphocytes to the inflamed mucosa. Biomed Res Int. 2013;2013:408638.

77. Järnerot G, Tysk C, Bohr J, Eriksson S. Collagenous colitis and fecal stream diversion. Gastroenterology. 1995;109(2):449-455.

78. Kumawat AK, Strid H, Tysk C, Bohr J, Hörnquist EH. Microscopic colitis patients demonstrate a mixed Th17/Tc17 and Th1/Tc1 mucosal cytokine profile. Mol Immunol. 2013;55(3-4):355-364.

79. Tagkalidis PP, Gibson PR, Bhathal PS. Microscopic colitis demonstrates a T helper cell type 1 mucosal cytokine profile. J Clin Pathol. 2007;60(4):382-387.

80. Günaltay S, Nyhlin N, Kumawat AK, et al. Differential expression of IL-1/TLR signaling regulators in microscopic and ulcerative colitis. World J Gastroenterol. In press 2014.

81. Taha Y, Carlson M, Thorn M, Loof L, Raab Y. Evidence of local eosinophil activation and altered mucosal permeability in collagenous colitis. Dig Dis Sci. 2001;46(4):888-897.

82. Taha Y, Raab Y, Larsson A, et al. Mucosal secretion and expression of basic fibroblast growth factor in patients with collagenous colitis. Am J Gastroenterol. 2003;98(9):2011-2017.

83. Taha Y, Raab Y, Larsson A, et al. Vascular endothelial growth factor (VEGF) - a possible mediator of inflammation and mucosal permeability in patients with collagenous colitis. Dig Dis Sci. 2004;49(1): 109-115.

84. Griga T, Tromm A, Schmiegel W, Pfisterer O, Müller KM, Brasch F. Collagenous colitis: implications for the role of vascular endothelial growth factor in repair mechanisms. Eur J Gastroenterol Hepatol. 2004;16(4):397-402.

85. Salas A, Fernández-Bañares F, Casalots J, et al. Subepithelial myofibroblasts and tenascin expression in microscopic colitis. Histopathology. 2003;43(1):48-54.

86. Medina C, Radomski MW. Role of matrix metalloproteinases in intestinal inflammation. $J$ Pharmacol Exp Ther. 2006;318(3): 933-938.

87. Günther U, Schuppan D, Bauer M, et al. Fibrogenesis and fibrolysis in collagenous colitis. Patterns of procollagen types I and IV, matrix-metalloproteinase-1 and -13, and TIMP-1 gene expression. Am J Pathol. 1999;155(2):493-503.

88. Lundberg JO, Herulf M, Olesen M, et al. Increased nitric oxide production in collagenous and lymphocytic colitis. Eur J Clin Invest. 1997;27(10):869-871.

89. Olesen M, Middelveld R, Bohr J, et al. Luminal nitric oxide and epithelial expression of inducible and endothelial nitric oxide synthase in collagenous and lymphocytic colitis. Scand J Gastroenterol. 2003;38(1): 66-72.

90. Perner A, Andresen L, Normark M, et al. Expression of nitric oxide synthases and effects of L-arginine and L-NMMA on nitric oxide production and fluid transport in collagenous colitis. Gut. 2001;49(3): 387-394. 
91. Perner A, Nordgaard I, Matzen P, Rask-Madsen J. Colonic production of nitric oxide gas in ulcerative colitis, collagenous colitis and uninflamed bowel. Scand J Gastroenterol. 2002;37(2):183-188.

92. Bonderup OK, Hansen JB, Madsen P, Vestergaard V, Fallingborg J, Teglbjaerg PS. Budesonide treatment and expression of inducible nitric oxide synthase mRNA in colonic mucosa in collagenous colitis. Eur J Gastroenterol Hepatol. 2006;18(10):1095-1099.

93. Münch A, Söderholm JD, Wallon C, Öst A, Olaison G, Ström M. Dynamics of mucosal permeability and inflammation in collagenous colitis before, during, and after loop ileostomy. Gut. 2005;54(8): 1126-1128.

94. Münch A, Söderholm JD, Öst A, Ström M. Increased transmucosal uptake of $E$. coli $\mathrm{K} 12$ in collagenous colitis persists after budesonide treatment. Am J Gastroenterol. 2009;104(3):679-685.

95. Bohr J, Nordfelth R, Järnerot G, Tysk C. Yersinia species in collagenous colitis: a serologic study. Scand J Gastroenterol. 2002;37(6): 711-714.

96. Erim T, Alazmi WM, O’Loughlin CJ, Barkin JS. Collagenous colitis associated with Clostridium difficile: a cause effect? Dig Dis Sci 2003;48(7):1374-1375.

97. Mäkinen M, Niemelä S, Lehtola J, Karttunen TJ. Collagenous colitis and Yersinia enterocolitica infection. Dig Dis Sci. 1998;43(6) 1341-1346.

98. Perk G, Ackerman Z, Cohen P, Eliakim R. Lymphocytic colitis: a clue to an infectious trigger. Scand J Gastroenterol. 1999;34(1):110-112.

99. LaSala PR, Chodosh AB, Vecchio JA, Schned LM, Blaszyk H. Seasonal pattern of onset in lymphocytic colitis. J Clin Gastroenterol. 2005;39(10):891-893.

100. Vigren L, Tysk C, Ström M, et al. Celiac disease and other autoimmune diseases in patients with collagenous colitis. Scand J Gastroenterol. 2013;48(8):944-950.

101. Wang Y, Liu XP, Zhao ZB, Chen JH, Yu CG. Expression of CD4 ${ }^{+}$ forkhead box $\mathrm{P} 3$ (FOXP3)+ regulatory $\mathrm{T}$ cells in inflammatory bowel disease. J Dig Dis. 2011;12(4):286-294.

102. Götlind YY, Raghavan S, Bland PW, Hörnquist EH. CD4+FoxP3+ regulatory $\mathrm{T}$ cells from $\mathrm{G \alpha i} 2-/-$ mice are functionally active in vitro, but do not prevent colitis. PLoS One. 2011;6(9):e25073.

103. Fernández-Bañares F, de Sousa MR, Salas A, et al. Epidemiological risk factors in microscopic colitis: a prospective case-control study Inflamm Bowel Dis. 2013;19(2):411-417.

104. Vigren L, Sjöberg K, Benoni C, et al. Is smoking a risk factor for collagenous colitis? Scand J Gastroenterol. 2011;46(11): 1334-1339.

105. Yen EF, Pokhrel B, Du H, et al. Current and past cigarette smoking significantly increase risk for microscopic colitis. Inflamm Bowel Dis. 2012;18(10):1835-1841.

106. Fernández-Bañares F, de Sousa MR, Salas A, et al. Impact of current smoking on the clinical course of microscopic colitis. Inflamm Bowel Dis. 2013;19(7):1470-1476.

107. Beaugerie L, Pardi DS. Review article: drug-induced microscopic colitis - proposal for a scoring system and review of the literature. Aliment Pharmacol Ther. 2005;22(4):277-284.

108. Miehlke S, Madisch A, Kupcinskas L, et al. Budesonide is more effective than mesalamine or placebo in short-term treatment of collagenous colitis. Gastroenterology. 2014;146(5):1222-1230.

109. Chande N, McDonald JW, Macdonald JK. Interventions for treating lymphocytic colitis. Cochrane Database Syst Rev. 2008;(2): CD006096.

110. Chande N, McDonald JW, Macdonald JK. Interventions for treating collagenous colitis. Cochrane Database Syst Rev. 2008;(2):CD003575.

111. Baert F, Schmit A, D’Haens G, et al. Budesonide in collagenous colitis: a double-blind placebo-controlled trial with histologic follow-up. Gastroenterology. 2002;122(1):20-25.

112. Bonderup OK, Hansen JB, Birket-Smith L, Vestergaard V, Teglbjaerg PS, Fallingborg J. Budesonide treatment of collagenous colitis: a randomised, double blind, placebo controlled trial with morphometric analysis. Gut. 2003;52(2):248-251.
113. Miehlke S, Heymer P, Bethke B, et al. Budesonide treatment for collagenous colitis: a randomized, double-blind, placebo-controlled, multicenter trial. Gastroenterology. 2002;123(4):978-984.

114. Miehlke S, Madisch A, Karimi D, et al. Budesonide is effective in treating lymphocytic colitis: a randomized double-blind placebocontrolled study. Gastroenterology. 2009;136(7):2092-2100.

115. Bonderup OK, Hansen JB, Teglbjaerg PS, Christensen LA, Fallingborg JF. Long-term budesonide treatment of collagenous colitis: a randomised, double-blind, placebo-controlled trial. Gut. 2009;58(1):68-72.

116. Miehlke S, Madisch A, Bethke B, et al. Oral budesonide for maintenance treatment of collagenous colitis: a randomized, double-blind, placebocontrolled trial. Gastroenterology. 2008;135(5):1510-1516.

117. Miehlke S, Hansen JB, Madisch A, et al. Risk factors for symptom relapse in collagenous colitis after withdrawal of short-term budesonide therapy. Inflamm Bowel Dis. 2013;19(13):2763-2767.

118. Münch A, Bohr J, Miehlke S, et al. Low-dose budesonide is an effective maintenance therapy in collagenous colitis: results from the randomised, placebo-controlled BUC-63/COC-trial. United European Gastroenterol J. 2013;1(1S):A35.

119. Munck LK, Kjeldsen J, Philipsen E, Fischer Hansen B. Incomplete remission with short-term prednisolone treatment in collagenous colitis a randomized study. Scand J Gastroenterol. 2003;38(6):606-610.

120. Gentile NM, Abdalla AA, Khanna S, et al. Outcomes of patients with microscopic colitis treated with corticosteroids: a population-based study. Am J Gastroenterol. 2013;108(2):256-259.

121. Calabrese C, Fabbri A, Areni A, Zahlane D, Scialpi C, Di Febo G. Mesalazine with or without cholestyramine in the treatment of microscopic colitis: randomized controlled trial. J Gastroenterol Hepatol. 2007;22(6):809-814.

122. Wildt S, Munck LK, Vinter-Jensen L, et al. Probiotic treatment of collagenous colitis: a randomized, double-blind, placebo-controlled trial with Lactobacillus acidophilus and Bifidobacterium animalis subsp. lactis. Inflamm Bowel Dis. 2006;12(5):395-401.

123. Madisch A, Miehlke S, Eichele O, et al. Boswellia serrata extract for the treatment of collagenous colitis. A double-blind, randomized, placebo-controlled, multicenter trial. Int $J$ Colorectal Dis. 2007;22(12):1445-1451.

124. Pardi DS, Loftus EV Jr, Tremaine WJ, Sandborn WJ. Treatment of refractory microscopic colitis with azathioprine and 6-mercaptopurine. Gastroenterology. 2001;120(6):1483-1484.

125. Münch A, Fernández-Bañares F, Munck LK. Azathioprine and mercaptopurine in the management of patients with chronic, active microscopic colitis. Aliment Pharmacol Ther. 2013;37(8): 795-798.

126. Riddell J, Hillman L, Chiragakis L, Clarke A. Collagenous colitis: oral low-dose methotrexate for patients with difficult symptoms: long-term outcomes. J Gastroenterol Hepatol. 2007;22(10):1589-1593.

127. Münch A, Bohr J, Vigren L, Tysk C, Ström M. Lack of effect of methotrexate in budesonide-refractory collagenous colitis. Clin Exp Gastroenterol. 2013;6:149-152.

128. Aram G, Bayless TM, Chen ZM, Montgomery EA, Donowitz M, Giardiello FM. Refractory lymphocytic enterocolitis and tumor necrosis factor antagonist therapy. Clin Gastroenterol Hepatol. 2010;8(4):391-394.

129. Esteve M, Mahadevan U, Sainz E, Rodriguez E, Salas A, Fernández-Bañares F. Efficacy of anti-TNF therapies in refractory severe microscopic colitis. J Crohns Colitis. 2011;5(6):612-618.

130. Münch A, Ignatova S, Ström M. Adalimumab in budesonide and methotrexate refractory collagenous colitis. Scand J Gastroenterol. 2012;47(1):59-63.

131. Pola S, Fahmy M, Evans E, Tipps A, Sandborn WJ. Successful use of infliximab in the treatment of corticosteroid dependent collagenous colitis. Am J Gastroenterol. 2013;108(5):857-858.

132. Fine KD, Ogunji F, Lee E, Lafon G, Tanzi M. Randomized, double blind, placebo-controlled trial of bismuth subsalicylate for microscopic colitis. Gastroenterology. 1999;116(4):A880. 
133. Varghese L, Galandiuk S, Tremaine WJ, Burgart LJ. Lymphocytic colitis treated with proctocolectomy and ileal J-pouch-anal anastomosis: report of a case. Dis Colon Rectum. 2002;45(1):123-126.

134. Hjortswang H, Tysk C, Bohr J, et al. Health-related quality of life is impaired in active collagenous colitis. Dig Liver Dis. 2011;43(2): 102-109.
135. Hjortswang H, Tysk C, Bohr J, et al. Defining clinical criteria for clinical remission and disease activity in collagenous colitis. Inflamm Bowel Dis. 2009;15(12):1875-1881.

136. Madisch A, Heymer P, Voss C, et al. Oral budesonide therapy improves quality of life in patients with collagenous colitis. Int $J$ Colorectal Dis. 2005;20(4):312-316.

\section{Publish your work in this journal}

Clinical and Experimental Gastroenterology is an international, peerreviewed, open access journal, publishing all aspects of gastroenterology in the clinic and laboratory, including: Pathology, pathophysiology of gastrointestinal disease; Investigation and treatment of gastointestinal disease; Pharmacology of drugs used in the alimentary tract;
Immunology/genetics/genomics related to gastrointestinal disease. This journal is indexed on CAS. The manuscript management system is completely online and includes a very quick and fair peer-review system. Visit http://www.dovepress.com/testimonials.php to read real quotes from published authors.

Submit your manuscript here: http://www.dovepress.com/clinical-and-experimental-gastroenterology-journal 